\title{
Pemanfaatan Ruang Publik Sebagai Peningkatan Partisipasi Politik di Nagari Talang Anau, Kabupaten Lima Puluh Kota
}

\author{
${ }^{1}$ Tengku Rika Valentina, ${ }^{2}$ Aidinil Zetra, ${ }^{3}$ Lusi Puspika Sari \\ ${ }^{123}$ Jurusan Ilmu Politik, Fakultas Ilmu Sosial dan Ilmu Politik, Universitas Andalas, \\ Kota Padang, Indonesia, 25175 \\ E-mail: tengkurika@soc.unand.ac.id ; aidinil@soc.unand.ac.id : lusipuspikasari@gmail.com \\ Received: 16 Maret 2020; Revised: 11 April 2020; Accepted: 02 Juni 2020
}

\begin{abstract}
The purpose of this paper is to explain the function of the publik sphere in increasing the political participation of the people in Nagari Talang Anau. This research uses a qualitative method with a case study approach.. The data technique was carried out through observation, interviews, and documentation. The results of this study indicate that coffee shops or terms in Minangkabau, especially Nagari Talang Anau Lapau Kopi, are a form of publik space. Activities carried out at "Lapau Kopi" are not limited to drinking coffee or tea in general. However, at Nagari Talang Anau, "Lapau Kopi" will be used as a place to discuss releasing the burden of the mind and dissolving the saturation point of work. The discussions that took place between these individuals started from light discussions to the problems that occurred in Nagari Talang Anau in a social, economic, political, and cultural context. The discussion that took place in "Lapau Kopi" shows a concept of deliberation as the term in the concept of deliberative democracy spurs on processes that occur in determining decisions or policies, such as collective deliberations in publik spaces that produce a publik opinion that can encourage people to plan and plan. Development in Nagari Talang Anau and increasing awareness of the issues discussed and influencing the policies of the Talang Anau Nagari Government, Gunung Omeh District.
\end{abstract}

Keywords: Nagari; Public Space; Political Participation; Democracy

\begin{abstract}
Abstrak
Tujuan dari tulisan ini adalah untuk menjelaskan fungsi ruang publik dalam meningkatkan partisipasi politik masyarakat di Nagari Talang Anau. Penelitian ini menggunakan metode kualitatif dengan pendekatan studi kasus. Teknik pengumpulan data dilakukan melalui observasi, wawancara, dan dokumentasi. Hasil dari penelitian ini menunjukkan bahwa warung kopi atau istilah dalam Minangkabau khususnya Nagari Talang Anau Lapau Kopi merupakan salah satu bentuk ruang publik. Aktivitas yang dilakukan di Lapau Kopi tidak hanya sebatas minum kopi atau teh saja pada umumnya, akan tetap di Nagari Talang Anau lapau kopi dijadikan sebagai tempat berdiskusi melepaskan beban pikiran dan melarutkan titik kejenuhan dari pekerjaan. Diskusi yang terjalin antara individu tersebut dimulai dari pembahasan yang ringan hingga permasalahan yang terjadi di Nagari Talang Anau dalam konteks sosial, ekonomi, politik dan budaya. Perbincangan yang terjadi di lapau kopi ini menunjukan suatu konsep musyawarah seperti yang dijelaskan dalam konsep demokrasi deliberatif memacu pada proses-proses yang terjadi dalam penentuan suatu keputusan atau kebijakan, seperti adanya musyawarah bersama di ruang publik yang menghasilkan opini publik yang mampu yang mendorong masyarakat untuk berpartisipasi dalam kegiatan perencanaan dan pembangunan di Nagari Talang Anau dan meningkatkan kepedulian terhadap isu yang dibahas dan mempengaruhi kebijakan Pemerintahan Nagari Talang Anau Kecamatan Gunung Omeh.
\end{abstract}

Kata Kunci: Nagari: Ruang Publik: Partisipasi Politik: Demokrasi

Link DOI : http://dx.doi.org/10.31314/pjia.9.1.66-79.2020 


\section{PENDAHULUAN}

Diskursus mengenai kajian ruang publik sebagai salah satu bentuk peningkatan partisipasi dalam masyarakat menjadi kajian menarik diberbagai khazanah ilmu pengetahuan, khususnya dalam ranah politik. Ruang publik muncul sebagai suatu prasyarat yang harus dimiliki dan dikembangkan dalam negara yang menganut system demokrasi, dalam upaya untuk dapat menjamin ideal nya penyelenggaraan suatu pemerintahan yang demokratis. Keberadaan ruang publik juga merupakan bentuk penting untuk meningkatkan partisipasi masyarakat dalam mengawal setiap kebijakan pemerintah, melalui dirkusus yang rasional tanpa adanya intervensi, sehingga konsep demokrasi yang deliberative dapat muncul (Prasetyo, 2012). Partisipasi masyarakat dalam pembentukan ruang publik ini nantinya akan melahirkan sikap-sikap politik dalam masyarakat. Pada dasarnya, ruang publik, partisipasi masyarakat untuk menghasilkan kosensus dan demokrasi deliberative merupakan tiga hal yang tidak terpisahkan.

Menurut Habersmas, demokrasi dapat berjalan dengan baik jika dalam sesuatu negara terdapat ruang publik yang setara (egaliter), dimana setiap orang memiliki kesempatan yang sama untuk berpartisipasi dan menyampaikan idenya. Secara defenitif, menurut Habermas dalam (Prasetyo, 2012), ruang publik dapat di defenisikan sebagai ruang yang berada diantara komunitas ekonomi dan negara, yang mana publik dapat melakukan diskusi yang bersifat rasional, sehingga membentuk opini mereka, dan dapat menjalankan pengawasan terhadap pemerintah. Ruang publik merupakan tempat yang dapat digunakan segala lapisan masyarakat untuk dapat ikut berpartisipasi, dengan adanya perundingan, menunjukkan adanya lapisan masyarakat dalam keseluruhan kegiatan tersebut. Dalam masyarakat tradisional maupun modern keberadaan ruang publik sangatlah penting.

Dalam masyarakat tradisional, bentuk-bentuk ruang publik sangatlah sepesifik seperti balai desa, pendopo, cakruk atau teras rumah kepala desa yang berfungsi sebagai tempat berkumpul untuk berdiskusi guna berbicara atau-pun memecahkan persoalan yang ada, atau hanya sebagai ruang untuk bertegur sapa dan beramah tamah (Nugroho \& Kamajaya, 2019). Berkembangnya zaman membuat ruang publik menjamur di setiap daerah dalam berbagai bentuk yang bervariasi, sehingga dibutuhkan ruang publik yang benar-benar representatif untuk semua kalangan tanpa adanya klasifikasi sosial. Keberadaan forum-forum diskursus warga untuk menanggapi isu-isu lokal daerah dan nasional merupakan wujud konkrit dari partisipasi yang melibatkan masyarakat didalamnya. Salah satu nya Nagari, Desa/Nagari sebutan di Sumatera Barat sebagai pemerintahan terendah mempunyai kuasa penuh untuk meningkatkan pembangunannya sendiri demi kesejahteraan masyarakat. Ruang Publik menjadi salah satu kebutuhan masyarakat lokal di nagari sehingga terjalin interaksi sosial. Partisipasi masyarakat nagari akan menentukan pembentukan ruang publik. Keberadaan ruang publik khususnya ruang publik politik di tengah kehidupan masyarakat dapat memacu kepedulian masyarakat dalam pembangunan nagari serta pada pengambilan keputusan. Salah satu fungsinya adalah sebagai pusat interaksi untuk kegiatan kegiatan masyarakat lokal baik formal maupun informal yang bersifat demokratik dan dapat menerima kehadiran berbagai lapisan masyarakat dengan bebas tanpa ada diskriminasi. Seperti yang dialog, dan perencanaan yang tidak Copyright (c) 2020, Publik (Jurnal Ilmu Administrasi), ISSN: 2301-573X (Print), ISSN: 2581-2084 (Online) 
diungkap oleh Arent dalam (Hardiman, 2010) menyebutkan ruang publik sebagai ruang penampakan, artinya suatu ruang tempat orang-orang saling berinteraksi dengan cara bertindak dan berbicara. Ruang ini-lah yang menjadi dasar semua pendirian dan bentuk Negara. Ruang tersebut secara potensial ada dalam setiap lapisan masyarakat, Arendt dalam (Hardiman, 2010) memikirkan, ruang publik sebagai sesuatu yang sejak awal tidak terkontaminasi terhadap kepentingankepentingan kekuasaan rezim (kekuasaan) dan kepentingan ekonomis. Ruang publik terbentuk karena ada suatu keinginan yang tulus dari masyarakat dalam beberapa kesenjangan sosial yang terjadi. Hal ini juga diungkap oleh E, Budiharjo \&Djoko $\mathrm{S}$ (1999) dalam (Malik, 2018) Keberadaan ruang publik menjadi bagian penting bagi masyarakat sebagai upaya untuk mengatasi terjadinya konflik sosial yang mengarah kepada terciptanya disharmoni dan disintegrasi social melalui penyedian ruang terbuka bersama (open publik space) seperti : lapangan olahraga, poliklinik, tempat ibadah, lembaga pendidikan, pasar/mall/plaza, taman dll. Bagi Habermas dan Arend dalam (Cassegard, 2014) keduanya memberikan penekanan khusus terhadap fungsi ruang publik sebagai arena verbal, kontestasi, musyawarah dan debat.

Bagi Habermas ruang publik adalah ranahnya validitas yang didasari oleh penggunaan publik oleh masyarakat atas alasan mereka sendiri untuk datang bersama-sama akan tujuan politik melalui debat dan manifestasi, argument yang diperbincangkan. Arendt juga melihat aksi politik juga berkaitan dengan pembicaraan publik, ruang publik muncul setiap kali orang berkumpul untuk memutuskan urusan bersama melalui diskusi, media pidato, persuasi. Ia juga mengklaim bahwa,
Sebagian besar tindakan politik adalah ditransaksikan dengan kata-kata.

Kebutuhan masyarakat terhadap ruang publik sebagai sebuah sarana melakukan aktivitas dengan beragam kegiatan secara bersama-sama diwujudkan melalui interaksi social yang diakomodasi dalam ruang publik, sehingga adanya pembelajaran antara masyarakat secara terus menerus sehingga muncul pemahaman yang sama. Ruang publik ini sejatinya telah terbentuk secara sosiohistoris di masyarakat pedesaan, yang dikenal dengan konsep demokrasi politik musyawarah (rembug desa), atau yang juga dikenal sebagai musrenbang, pelaksanaan musrenbang ini sejalan dengan demokrasi yang deliberative. Bentuk lain dari sejarah ruang publik yaitu tidak dapat dipisahkan dari kemunculan warung-warung kopi pada era kapitalisme awal, pada abad ke 13 di Eropa. Warung kopi dapat menjadi ruang publik baru ketika itu. Menjadi arena diskursus bagi warga masyarakat yang sedang bertumbuh dari masyarakat feodal ke masyarakat borjuis. Ciri utama dari interaksi di warung kopi adalah sifatnya yang lebih spontan, otentik, dan komunikatif. Hubungan antar individu di warung kopi cenderung bersifat asimetris dan tidak hirarkis, status sosial tidak begitu penting, bahkan sangat cair. Dari rakyat biasa sampai pejabat tinggi, dari buruh sampai pemilik modal, semuanya dapat berbaur, saling melempar gagasan, dan saling adu argumentasi (Paulangi, 2018).

Menariknya fenomena nagari sebagai bagian pemerintahan terendah di Sumatera Barat, ruang publik merupakan salah satu kebutuhan pokok bagi masyarakat lokal sehingga terjalinnya interaksi sosial antara masyarakat. Kehadiran Warung kopi pada abad 13, mengisyaratkan bahwa ruang itu memang benar ada dalam konteks 
Publik (Jurnal Ilmu Administrasi) Vol 9 (1), Juni 2020

pemerintahan local salah satunya Nagari di

Sumatera Barat yang di sebut dengan nama

Lapau kopi walaupun memang terdapat beberapa perbedaan yang mencolok dibandingkan dengan sosio-historis dahulunya. Nagari Talang Anau merupakan salah satu Nagari di Kabatupaten Lima Puluh Kota yang cukup jauh dari pusat kota, ini membuat Nagari Talang Anau masih kuat memegang adat istiadat dalam kehidupan sehari-hari dan dalam ber-Nagari. Kearifan local pada masyarakat Talang Anau masih tidak terkontaminasi oleh perkembangan era digital saat sekarang ini. Semangat gotongroyong dan saling bekerja sama dalam menyelesaikan permasalahan baik privat maupun publik masih terasa kuat di Talang Anau.

Hal ini menciptakan lebih banyak ruang yang tercipta dalam tatanan kehidupan bermasyarakat di nagari ini, dengan demikian keberadaan ruang publik akan lebih besar. Di Talang Anau masyarakat biasa berkumpul dan juga bercengkrama, ini juga sudah lekat dengan budaya setempat, masyarakat yang sebelumnya tidak saling kenal akan saling mengenal satu sama lain dengan memanfaatkan warung-warung kopi (lapau kopi) untuk sekedar berkumpul dan bertukar cerita. Di nagari ini masyarakat menganggap Lapau kopi bukan hanya sebagai tempat minum kopi seperti biasanya, tetapi telah dialihfungsikan sebagai tempat mereka berdiskusi secara terbuka, bertukar fikiran, membahas tentang berbagai macam permasalahan dan persoalan yang ada disekitarnya, bahkan berbagai masalah pemerintahan nagari pun dibahas di Lapau kopi tersebut, serta menyinggung beberapa hal yang berkaitan dengan anak muda dan perilakunya. Oleh karenya menarik bagi peneliti untuk melihat sejauh manakah ruang publik mampu untuk meningkatkan partisipasi masyarakat di nagari Talang Anau terhadap situasi pemerintahan nagari. Tujuan dari penelitian ini yang peneliti rumuskan adalah 1) Untuk mengetahui, menjelaskan, serta menganalisis bagaimana fungsi ruang publik sehingga dapat meningkatkan partisipasi politik di Nagari; 2) Untuk mengetahui, menjelaskan serta menganalisis bagaimana masyarakat di Nagari Talang Anau mampu memanfaatkan ruang publik sebagai bagian dari partisipasi masyarakat.

Beberapa Peneliti terdahulu yang telah peneliti soroti diantaranya (Nugroho \& Kamajaya, 2019); (Iskandar, 2017); (Bhakti, 2020) (Setiawan, Leksono, \& Sungkawati, 2020) (Geraldy, 2017) yang memiliki fokus penelitian yang berbedabeda, dari beberapa penelitian tersebut cenderung lebih berfokus pada hiburan, interaksi, komunikasi dan media masa atau sosial sebagai sarana ruang publik. Lain dari pada itu ada yang berfokus pada alokasi ruang dan juga kajian kewilayahan. Selain locus yang berbeda dalam beberapa penelitian diatas, penelitian ini mengkaji dari sudut politis ruang publik, yang mana ruang tersebut dimanfaatkan sebagai sarana interaksi masyarakat dalam meningkatkan partisipasti masyarakat terhadap Pemerintahan Nagari baik dalam segi pembangunan dan isu sosial dalam masyarakat Nagari. Ruang ini hadir dalam bentuk fisik yang bisa di tempati oleh masyarakat untuk bertukar pikiran, melepas lelah setelah bekerja, dan menyampaikan keresahan terhadap kondisi yang terjadi di masyarakat.

Dalam Penelitian ini peneliti menggunakan Konsep Ruang publik dan partisipasi politik untuk membantu peneliti menganalisis persoalan yang terjadi dilapangan. Konsep ruang publik sendiri terus berubah dengan kebutuhan yang dilandasi nilai normative dari diskusi dan debat rasional kritis. Untuk ini perlu Copyright (c) 2020, Publik (Jurnal Ilmu Administrasi), ISSN: 2301-573X (Print), ISSN: 2581-2084 (Online) 
disadari bahwa melakukan klarifikasi atas konsep ruang publik merupakan suatu hal yang tidak mudah, mengingat adanya keberagaman makna dan pengertian yang luas dari konsep tersebut. Istilah ruang publik seringkali digunakan secara longgar, hal ini sangat dipengaruhi oleh konteks dan ilmu yang sedang mengartikulasikannya. Misalnya, dalam ilmu arsitektur dan planologi, ruang publik dipahami dalam pengertian teknisarsitektural, dengan taman, plaza, dan ruang terbuka sebagai contoh dari apa yang disebut ruang publik. Dalam konteks dunia digital internet, ruang publik adalah cyberspace tempat interaksi maya terjadi. Bagi pengkaji dan aktivis media, ruang publik adalah perusahaan penyiaran yang disponsori oleh pemerintah. (Prasetyo, 2012).

Apa yang membuat Habermas tertarik dengan ide tentang ruang publik adalah potensinya sebagai fondasi dari masyarakat yang dibangun atas dasar prinsip-prinsip demokrasi (Johnson, 2006:19 dalam (Prasetyo, 2012)). Menurut Habermas (1985) ruang publik adalah ruang di mana warganegara bisa berunding mengenai hubungan bersama mereka sehingga merupakan sebuah arena institusi untuk berinteraksi pada hal-hal yang berbeda. Arena ini secara konseptual berbeda dengan negara, yaitu tempat untuk melakukan produksi dan sirkulasi diskursus yang bisa secara prinsip merupakan hal yang sangat penting bagi negara (Hardiman, 2009). Arendt (dalam Budi Hardiman, 2010) memikirkan, ruang publik sebagai sesuatu yang sejak awal tidak terkontaminasi terhadap kepentingankepentingan kekuasaan rezim (kekuasaan) dan kepentingan ekonomis. Secara historisnya, ruang publik muncul pertama kali pada abad ke-17 di Eropa, dalam kemunculannya ini bersamaan dengan berkembangnya kapitalisme. Pada masa inilah muncul kelas baru dalam masyarakat yaitu kelas borjuis. Dalam hubungannya dengan negara, ruang publik memiliki peran sebagai intermediasi antara negara dan kaum borjuis. Melalui opini-opini yang disampaikan dalam ruang publik, tersimpan misi agar negara lebih responsive terhadap kebutuhan dan kepentingan kaum borjuis.

Menurut Habermas (1989) dalam (Prasetyo, 2012) menekankan terdapat tiga ideal normative yang inheren dalam konsep ruang publik. Pertama, ruang publik sejenis pergaulan social yang sama sekali tidak menyamakan status antar orang karena secara konsepnya tidak memiliki signifikansi apapun. Dalam hal ini preferensi kedudukan tersebut diganti dengan nilai kebijaksanaan yang setara dengan nilai persamaan setiap orang. Dalam ruang publik yang menduduki tempat yang lebih tinggi bukan status, pangkat, harta, atau keturunan, melainkan argument yang lebih baik. Kedua, meskipun setiap orang memiliki kepentingan yang berbeda mungkin bisa dipengaruhi oleh perbedaan status, kepentingan sendiri juga dianggap tidak memiliki signifikansi. Yang menyatukan orang-orang bertemu di ruang publik adalah kesamaan akan penggunaan rasio berkarakter "tanpa kepentingan" atau (dis interested "interest of reason"), artinya pendapat yang muncul dalam ruang publik harus berlandaskan kepada kepentingan umum, bukan kepentingan particular. Ketiga, pada prinsipnya ruang publik bersifat inklusif, hal ini dapat terlihat dari formalitas syarat untuk berpartisipasi dalam ruang publik, yang mana setiap masyarakat atau warga negara dapat menggunakan rasionalitasnya.

Teori ruang publik merupakan sebuah arena pembentukan ide, 
konstruksi pengetahuan bersama, dan konstruksi
opini, berlangsung ketika orang berkumpul dan berdiskusi. Menurut Habermas, ruang publik merupakan jaringan untuk mengkomunikasikan informasi dan sudut pandang. Ruang publik merupakan tempat berkomunikasi mengenai kegelisahan politis masyarakat, selain itu juga merupakan wadah bagi masyarakat dengan bebas dapat menyatakan sikap dan pendapat mereka kepada negara atau pemerintah. Habermas juga memberikan gagasan mengenai tidak terbatas nya keberadaan dari ruang publik, ada dimana saja. Ketika ada masyarakat berkumpul bersama, dan berdiskusi tentang tema yang relevan, maka disitu hadir ruang publik. Selain itu, ruang publik juga tidak terikat dengan kepentingan-kepentingan pasar maupun politik. Oleh karena itu, sifat dari ruang publik sendiri menjadi tidak terbatas. (Habermas, 1989)

Aspek penting dalam melihat kualitas demokrasi suatu negara dapat dilihat dari tingginya partisipasi politik warga negaranya. Ciri khas dari modernisasi politik adalah partisipasi politik, dengan adanya keputusan politik yang dibuat dan dilaksanakan oleh pemerintah menyangkut dan mempengaruhi kehidupan warga negara, maka warga negara berhak untuk ikut serta menentukan kebijakan politik suatu negara. Teori demokrasi liberal melihat bahwa pemilihan umum merupakan basis dan indicator untuk melihat derajat demokrasi. Partisipasi politik bagian dari variable penting demokrasi, yang juga sering dijadikan indicator untuk melihat keberhasilan Pemilu. Dahl memandang Pemilu yang dilaksanakan untuk memilih pemimpin dan perwakilan politik yang dilakukan secara regular, kompetitif, jujur merupakann pilar demokrasi. Sirkulasi elit dan kekuasaan ini secara lebih khusus dibedah oleh Mosca, Pareto, Michels dan C.W.Mills (Geraldy, Copyright @ 2020, Publik (Jurnal Ilmu Administrasi), ISSN: 2301-573X (Print), ISSN: 2581-2084 (Online)
2017). Berbagai bentuk partisipasi politik diberbagai negara dapat diklasifikasikan dalam kegiatan politik baik konvensional dan non konvensional, ada juga yang legal maupun illegal (cara kekerasan atau revolusi). Bentuk-bentuk partisipasi politik ini dapat dipakai sebagai ukuran untuk menilai stabilitas system politik, integritas politik, kepuasan atau ketidakpuasan warga negara.

Keberadaan ruang publik dalam hal ini juga merupakan salah satu bagian penting untuk meningkatkan partisipasi masyarakat, melalui diskursus yang rasional dengan tanpa ada tekanan, sehingga nantinya konsep deliberatif dapat dimunculkan dalam forum-forum tersebut. Pada dasarnya ruang publik, partisipasi politik masyarakat dan juga demokrasi deliberatif,merupakan tiga hal yang tidak dapat dipisahkan dalam pratiknya.

\section{METODE PENELITIAN}

Pendekatan dalam penelitian ini menggunakan metode kualitatif dengan pendekatan studi kasus, untuk mengeksplorasi dan memahami makna bagi sejumlah individu atau kelompok di anggap berasal dari masalah sosial atau kemanusiaan. Proses penelitian kualitatif ini melibatkan upaya-upaya penting, seperti mengajukan pertanyaan-pertanyaan dan prosedur-prosedur, menganalisis data secara induktif mulai dari tema-tema umum, dan menafsirkan makna data (Creswell, 2016). Penggunaan pendekatan kualitatif juga dikarenakan objek yang akan ditelah dari asumsi yang peneliti bangun, adanya peran Lapau kopi sebagai ruang publik masyarakat dalam mendorong partisipasi politik masyarakat. Selanjutnya bagaimana pemanfaatan Lapau kopi tersebut sebagai ruang publik. Penelitian ini dilakukan pada Desa/Nagari yang berada pada wilayah atau luhak yaitu Perwakilan nagari yang berada di Luhak 
Limapuluh Kota (Nagari Talang Anau). Sebaran lokasi penelitian yang ditetapkan mewakili bentuk- bentuk kearifan lokal yang dipakai dalam melihat praktik ruang publik pada nagari. Data dikumpulkan melalui observasi lapangan, wawancara dan dokumentasi. Data yang telah didapatkan dianalisis dengan prinsipprinsip metode kualitatif, yang artinya dikumpulkan melalui wawancara dijelaskan secara transkip. Adapun yang menjadi informan penelitian dalam penelitian ini adalah Wali Nagari, Wali Jorong, Ketua bamus (Badan Musyawarah), sekretaris nagari, ketua Kerapatan Adat Nagari (KAN), unsur masyarakat (Alim Ulama, Cadiak Pandai, Pemuda, Ninik Mamak).

Peneliti mencoba memahami dan menginterpretasikan informasi yang diperoleh kemudian dijelaskan secara kualitatif. Ini akan memperdalam Analisa peneliti dalam menelaah data secara sistematis. Hubungan tersebut akan peneliti paparkan sebagai proposisi sebagaimana didalam penelitian kualitatif lainnya, melalui sebuah tulisan yang bersifat deskriptif dan konseptual. Analisis ini dilakukan berdasarkan pandangan informan (emik) yang sudah di validasai menggunakan metode triangulasi, yang memperoleh kesimpulan dari analisis yang dilakukan terkait penggabungan data yang didapatkan baik dari informan dan interpretasi peneliti (etik) terhadap data dilapangan.

\section{HASIL DAN PEMBAHASAN}

Partisipasi politik masyarakat di nagari juga dipengaruhi oleh ruang publik yang terbentuk dalam masyarakat, ruang publik tercipta dalam semua tingkatan serta lapisan masyarakat, tak terkecuali dalam masyarakat lokal. Ruang publik adalah ruang yang digunakan masyarakat untuk saling berinteraksi dengan cara berdiskusi dan bertindak. Ruang ini secara tidak langsung merupakan dasar pendirian dan bentuk negara.

Beberapa hasil dari penelitian dahulu yang meneliti tentang ini yaitu diantaranya (Prasetyo, 2012) hasil dari penelitian ini menunjukan bahwa pembahasan ruang publik dalam ST (The Structural Transformation of Public Sphere) merujuk pada jenis ruang publik yang tunggal, yaitu ruang publik borjuis. Hal ini berbeda dengan BFN (Between Facts and Norms), di mana ruang publik bersifat plural masing-masing kelompok asosiasi dalam masyarakat dapat membentuk ruang publiknya sendiri. Selain itu juga ada penelitian dari (Paskarina, 2005) hasil penelitianya menyebutkan bahwa demokrasi deliberatif mendasarnya asumsi pada tindakan komunikatif dalam bentuk pertarungan wacana, arena tempat berlangsungnya pertarungan wacana inilah yang disebut dengan ruang publik. Oleh karena itu dalam konsepsi ini, ruang publik tidak diartikan secara fisik tetapi merupakan ruang sosial (sosial space) yang dihasilkan oleh tindakan komunikatif. Ruang publik menjadi tempat bagi terbentuknya opini publik yang merefleksikan isu isu yang berkembang dalam tataran elit maupun massa. Lain dari pada itu penelitian dari (Valentina, 2018) membahas terkait dengan dinamika politik lokal di Minangkabau, penelitian ini menghasilkan bahwa Lembaga Nagari (KAN) memposisikan diri sebagai ruang publik, sehingga KAN bisa diakses oleh seluruh anak kemenakan dalam nagari. Supaya terjalin komunikasi yang interes antara perwakilan suku di Nagari Panyakalan, dengan model komunikasi yang dibangun tetap secara oligarki (bajanjang naiak batanggo turun) dan egaliter musyawarah dan munfakat 
Dari beberapa hasil dari penelitian terdahulu juga berkaitan dengan ruang publik di Nagari Talang Anau. Lapau merupakan tempat yang tidak bisa dipisahkan dari kebudayaan dan karakter masyarakat Minangkabau selain rantau, dan surau, karena lapau telah menjadi ranah internal yang sama halnya dengan surau, akan tetapi berbeda dengan rantau yang menjadi ranah eksternal di Minangkabau. Dikutip dari Edward bord bahwa menurut Gusti Asnan dalam makalahnya pada 'Kongres Kebudayaan Indonesia' mengenai asal mulanya Lapau: "tidak diketahui, sejak kapan lapau mulai muncul di Minangkabau, namun bisa dikatakan lapau mulai menjadi bagian dari sistem sosial (juga politik dan ekonomi) Minangkabau ketika aktivitas niaga mulai marak di daerah itu. Lapau saat itu mulai menjadi 'lembaga' penting dalam jaringan niaga antara daerah pantai dan pedalaman Minangkabau".

Lapau memiliki fungsi tempat saudagar singgah atau bermalam, dikawasan pantai lapau menjadi tempat menginap para saudagar yang datang dari daerah pedalaman, terkadang lapau menjadi tempat mereka bertransaksi dengan saudagar lain. Disamping itu, lapau juga berfungsi untuk tempat berbagi informasi dari segala aspek termasuk menyoal kondisi sosial dan politik di daerah yang mereka lalui, Topik yang dibicarakan terkadang berubah-ubah sesuai kondisi dan tergantung pada keaktual kondisi saat ini.

Seiring dengan perkembangan zaman keberadaan lapau sebagai tempat singgah atau menginapnya para saudagar mulai berubah. Saat ini, lapau dijadikan sebagai sarana tempat jual beli kebutuhan harian, cenderung diisi oleh kaum laki-laki untuk berkumpul dan menghabiskan waktu berbincang dengan sesama pengunjung atau hanya melepas penat dari kegiatan Copyright ( 2020, Publik (Jurnal Ilmu Administrasi), ISSN: 2301-573X (Print), ISSN: 2581-2084 (Online) sehari-hari. Pengunjung yang datang biasanya juga masyarakat lingkungan sekitar, perbincangan yang dilakukan membahas berbagai persoalan mulai dari isu local sampai ke tingkat nasional melingkupi permasalahan sosial, ekonomi dan juga politik. Kegiatan ini dilakukan sambil minum kopi, teh, merokok, main kartu, domino atau remi. Meskipun Lapau Kopi telah menjadi bagian dari masyarakat Minangkabau dan sebagai tempat berkumpul untuk membahas berbagai persoalan seperti social, politik, ekonomi dan budaya tetapi tidak menjadikan lapau sebagai Lembaga atau institusi politik tradisional di Minangkabau. Setiap kegiatan yang ada dilingkup Nagari/Desa, lapau selalu menjadi tempat utama dalam menginformasikan kegiatan, karena dilapau informasi sangat cepat menyebar kepada masyarakat. Lapau yang sebelumnya hanya ada dibeberapa tempat, sekarang berkembang sangat pesat sekali. Bahkan dalam satu Korong/Dusun bisa mencapai 5-8 Lapau.

Dari segi setting lapau itu sendiri, berbeda dengan toko dimana tidak ada space untuk bercengkrama hanya sekedar interaksi antara pembeli dan penjual serta pembeli sesama pembeli. Di Lapau, terdapat ruang bercengkrama antar pembeli yang luas dimana banyak meja dan kursi. Di beberapa Lapau, meja dan kursi dibuat memanjang yang berukuran sekitar 4-5 meter dan lebar 1 meter, begitu juga kursi nya menyesuaikan ukuran mejanya. Sangat jarang sekali ada meja dan kursi yang berukuran kecil atau dengan ukuran persegi.

Fenomena Lapau kopi memiliki kekuatan yang signifikan dan mendorong masyarakat untuk saling bertemu, bertukar pendapat dan berbincang. Menurut asumsi peneliti faktor dominan yang mempengaruhi atau yang mendorong partisipasi politik pengunjung Lapau kopi 
dalam perencanaan pembagunan

khususnya di Nagari Talang Anau adalah Lapau kopi yang dijadikan tempat diskusi publik mulai dari permasalah ekonomi politik dan sosial dan menjadi pusat informasi publik. Dari pengamatan peneliti dengan adanya diskusi publik pengunjung memanfaatkan Lapau kopi sebagai tempat menyampaikan pendapat, berdiskusi dan bebas berbicara.

Kepublikan yang terjadi di Lapau kopi di Nagari Talang Anau ini sejalan konsep ruang publik yang dimaksud oleh Jurgen Habermas. Menurutnya ruang publik adalah ruang di mana masyarakat bisa berunding mengenai hubungan mereka yang bersifat kepentingan bersama. Adanya diskusi yang bebas di Lapau kopi juga menjadikan Lapau kopi di Nagari Talang Anau sebagai salah satu pusat informasi. Lapau kopi menjadi pintu masuknya informasi sosial, ekonomi, diskusi kritis dan termasuk diskusi politik maupun diskusi perencanan pembangunan.

Lapau Kopi sebagai Ruang Publik dan menjaring partisipasi politik masyarakat Di Nagari Talang Anau Ruang publik memiliki peranan penting khususnya di Nagari Talang Anau dengan makna dan fungsinya yang semakin mendapat legitimasi di masyarakat. Peneliti menemukan ada beberapa bentuk ruang publik di nagari talang anau yang memiliki peranan penting dalam perencanaan pembangunan, seperti kegiatan musrenbang, rapat jorong, rapat bamus, rapat KAN, dan rapat nagari serta diskusi publik yang terjadi di Lapau kopi. Forum yang berlangsunng kegiatan Musrenbang, rapat jorong, rapat Bamus dan KAN serta rapat nagari lebih bersifat formal dengan prosedur yang tersistematis. Sementara diskusi publik yang ada diLapau kopi terlaksana secara spontan, lebih bersifat informal dan pembahasan tidak berdasarkan perencanaan yang matang. Ruang publik di Lapau kopi menggambarkan ruang diskusi yang lebih terbuka untuk semua kalangan masyarakat Nagari Talang Anau.

Lapau kopi merupakan tempat paling popular di Nagari Talang khususnya lakilaki, seperti yang peneliti temukan bahwa Lapau kopi tidak sekedar minum kopi tetapi juga untuk menikmati minuman lain seperti teh talua (teh yang dikocok dengan telur dan diseduh air panas), teh panas atau dingin. Lebih dari sekedar tempat minum kopi atau teh talua,Lapau kopi mempunyai makna kultural yang sangat dekat dengan inti kebudayaan masyarakat di Nagari Talang Anau yang bersifat kolektivistik yang bertentangan dengan individualisme. Minuman kopi atau teh bukanlah pendorong yang utama bagi laki-laki untuk datang dan duduk di Lapau kopi. Hal tersebut juga menjadi tempat dimana berkumpulnya berbagai kalangan masyarakat, mulai dari petani, pemuda, sumando (semenda), pegawai negeri, pemuka adat, alim ulama (tuangku, labai, dll), wali nagari, wali jorong dll. Lapau kopi adalah ruang yang tidak bisa dilepaskan dari kebudayaan dan karakter masyarakat di nagari ini selain rantau dan surau. Dimana Lapau kopi menjadi ranah internal sama hal nya surau. Ranah internal disini dimaksudkan adalah hal atau ruang yang ada secara geografis yang fisiknya masih berada dalam lingkungan nagari, sedangkan rantau berada diranah eksternal. Menariknya dari keberadaan Lapau kopi ini yaitu terkait keberagaman topik yang dibahas sangat bervariasi, tergantung subjek yang membicarakannya. Topik tersebut mulai dari hal yang ringan hingga topik yang serius seperti keadaan lingkungan sekitar contohnya kemalingan, negosiasi jual beli mulai dari motor hingga barang elektronik, terkait pekerjaan, 
kehidupan sehari-hari, event nasional hingga dunia serta masalah isu-isu politik mulai dari nasional hingga tingkat local, termasuk permasalahan yang terjadi dalam pemerintahan nagari, seperti dana desa, pembangunan desa dan lainnya.

Peneliti melihat adanya perhatian dari para pengunjung Lapau kopi kepada urusan non-privat menimbulkan dorongan untuk lebih memperhatikan objek-objek yang terjadi di sekitar, yang sifatnya menyentuh kepentingan bersama. Termasuk di dalamnya isu-isu politik lokal, mulai dari pemilihan kapalo jorong, wali nagari, sampai presiden dan pembangunan nagari. Pembicaraan tentang kemaslahatan bersama selanjutnya mendorong para pengunjungLapau kopi untuk lebih sensitif terhadap apa yang terjadi di lingkungan mereka. Tanpa pemahaman yang mendalam tentang lingkungan, mereka tidak akan dapat menjadi peserta aktif dalam diskusi dan hanya akan menjadi pendengar yang dianggap pendiam.

Ruang publik memiliki arti yang lebih luas bentuk fisiknya, tidak hanya sebuah ruang yang bersifat pasif. Sebaliknya, ruang publik mengarah kepada sebuah ruang yang aktif membentuk pemikiran dan pemahaman dalam masyarakat. Disini-lah ruang publik memiliki makna yang menentukan setiap kondisi dan aktivitas masyarakat yang berperan dalam membentuk persepsi, pengalaman dan tindak sosial. Dari hasil observasi peneliti, kehadiran Lapau kopi kopi telah mengait individu dan masyarakat dalam membentuk opini publik, mengekspresikan secara langsung kebutuhan dan kepentingan masyarakat sehingga dapat mempengaruhi kebijakan/praktik politik. Dimana aktivitas pengunjung Lapau kopi menjadi bagian dari kebebasan dalam kehidupan berdemokrasi dalam nagari, salah satu bentuknya adalah partisipasi politik.

Pelaksanaan musyawarah dalam Lapau kopi di nagari ini berbeda dengan yang dikemukakan oleh Habermas dimana dalam ruang publik semua kalangan bisa berpendapat tanpa adanya tekanan, Senada dengan Habermas (Prasetyo, 2012) juga mengatakan keberadaan ruang publik juga merupakan bentuk penting untuk meningkatkan partisipasi masyarakat dalam mengawal setiap kebijakan pemerintah, melalui dirkusus yang rasional tanpa adanya intervensi, sehingga konsep demokrasi yang deliberative dapat muncul, namun fenomena yang ada di Lapau kopi di Talang Anau memperlihatkan adanya pengaruh budaya yang membuat perbincangan di Lapau kopi selaku ruang publik tetap tidak sebebas yang di kemukakan Habermas. Namun secara fisik maupun proses terbentuknya Lapau kopi sebagai ruang publik sejalan dengan yang dikatakan Habermas dimana dalam ruang ini masyarakat bisa berinteraksi dan berunding tentang permasalahan hidup bersama.

Diskusi yang di adakan di Lapau kopi ini sejalan dengan konsep demokrasi deliberatif, dimana demokrasi deliberatif mekanisme penentuan dalam pembuatan keputusan dilakukan dengan cara partisipasi warga secara langsung, bukan melalui voting atau perwakilan, melainkan melalui dialog, musyawarah dan pengambilan kesepakatan sehingga partisipasi dimungkinkan secara luas dan menghindari terjadinya penguasaan elit dalam pengambilan keputusan.

Dalam Hardiman (2009) teori demokrasi deliberative tidak berpusat pada penyusunan daftar aturan tertentu yang menunjukan apa yang harus dilakukan oleh warga negara, melainkan aturan yang dibuat sehingga warga negara mematuhi aturan tersebut. Artinya di sini demokrasi Copyright @ 2020, Publik (Jurnal Ilmu Administrasi), ISSN: 2301-573X (Print), ISSN: 2581-2084 (Online) 
deliberatif memacu pada proses proses yang terjadi dalam penentuan suatu keputusan atau kebijakan. Dalam proses proses ini yang paling ditekankan adalah sistem musyawarah, sejalan dengan kegiatan diskusi yang terjadi di Lapau kopi. Dalam demokrasi deliberatif membutuhkan masyarakat yang aktif, yang tidak membiarkan pemerintahannya berjalan tanpa kontrol dari sini lah muncul suatu bentuk partisipasi politik dan adanya aspek pendidikan politik masyarakat. Dengan adanya ruang untuk memperbincangkan isu isu yang ada dalam kehidupan masyarakat sehingga menghasilkan suara suara publik yang tersistematisasi dan secara konstruktif, bukan hanya melalui tindakan demonstrasi tetapi adanya forum forum dialog dengan mekanisme permusyawaratan dan difasilitasi melalui forum deliberatif.

Dalam konteks lokal fenomena perbincangan atau diskusi publik di lapau kopi menggambarkan keaktifan masyarakat dalam membahas isu isu yang berkembang. Salah satu yang peneliti bahas di sini tentang pemanfaatan dana desa, adanya diskusi publik atau musyarawarah pengunjung tentang perencanaan dan pembangunan dengan dana desa secara tidak langsung menghasilkan opini publik. Di samping, juga mendorong masyarakat untuk mengekspresikan secara langsung kebutuhan dan kepentingan mereka yang akan mempengaruhi praktik politik dalam bentuk partisipasi politik. Masyarakat menginginkan adanya alokasi dana desa untuk pembangunan nagari salah satu pembangunan Tk. Aspirasi masyarakat Talang Anau yang menjadi sebuah wacana dari masyarakat dibawa ke tingkat lebih lanjut tidak hanya sebatas di Lapau kopi bahkan dibawa ketingkat lanjut yaitu Musrenbang dengan pembahasan mengenai pembangunan sekolah TK yang sudah masuk dalam RKP tetapi permasalahannya pembangunan ini tidak mempunyai lahan untuk dibangun. Hal ini sangat menarik menjadi bahan diskusi bagi kita bersama, bahwa keberadaan Lapau kopi memang mengiring opini publik untuk disampaikan ke pihak pemerintah nagari. Diskusi yang awalnya ringan hingga meningkat menjadi serius membawa kepercayaan diri masyarakat untuk bersama-bersama menyalurkan kepada pihak pemerintah nagari. Terlihat sekali bahwa masyarakat memang memanfaatkan Lapau Kopi sebagai ruang publik terbuka untuk bersama-sama membangun Nagari sesuai dengan kebutuhan masyarakat di Nagari Talang Anau.

Dari penjelasan tersebut, sesuai dengan apa yang dikatakan Habermas dalam (Prasetyo, 2012), dalam tulisantulisannya Habermas bahwa ruang publik yang dimaksud lebih mengarah pada perspektif politik. Selain dari Habermas, ada juga banyak pemikir kontemporer yang membahas ruang publik dari perspektif politik seperti Arend, Fraser, Keane, Putnam, Taylor dll (Prasetyo, 2012). Ahli tersebut berbagi pandangan yang sama tentang ruang publik, bahwa ruang publik memainkan sebuah peran yang vital dalam penguatan demokrasi, yaitu sebagai ruang yang dihidupi oleh masyarakat sipil yang berfungsi sebagai intermediasi antara negara dan individu. Melalui ruang publik ini-lah politik yang dijalan secara formal dapat dikontrol, diawasi secara seksama oleh nalar publik. Habermas juga mengatakan bahwa, demokrasi dapat berjalan baik, jika dalam negara itu terdapat ruang publik yang setara (egaliter), dimana setiap orang memiliki kesempatan yang sama untuk ikut berpartisipasi dan mengemukakan idenya. 
Kasus di atas juga sejalan dengan konsep ruang publik yang dimaksud Habermas, kepublikan yang terjadi di Lapau kopi di Nagari Talang Anau sesuai dengan yang ditulis Habermas melalui tulisannya, yang memaparkan tentang sejarah perkembangan ruang publik.

Di awal abad 17 Secara historis ruang publik muncul pertama kali berbarengan dengan berkembangnya kapitalisme di eropa, di Inggris orang biasa berkumpul untuk berdiskusi secara tidak formal seperti disalon-salon, rumah minum atau warung kopi. Mereka berdiskusi tentang persoalan karya seni dan baca tulis serta melebar ke perdebatan ekonomi dan politik, serta di Perancis perdebatan semacam ini terjadi di salon-salon. Ruang publik adalah ruang dimana warga negara bisa berunding mengenai hubungan bersama mereka sehingga menjadi sebuah arena institusi atau berinteraksi pada halhal yang berbeda. Fenomena ini juga tergambar dalam kehidupan lapau kopi kopi yang ada di Nagari Talang Anau. Sejalan dengan yang dikatakan Habermas ketika aksi-aksi politik pengunjung kopi melalui diskusi diskusi bebas akhirnya menimbulkan dan menghadirkan ide-ide baru mengenai perencanaan dan pembangunan di Nagari, yang mana pada akhirnya ide-ide yang didapat dari perbincangan di lapau kopi ini menjadi satu pertimbangan oleh pemerintah nagari dalam mengambil keputusan dan dalam pelaksanaan pembangunan, masyarakat akan ikut andil dalam gotong royong yang di adakan.

Menanggapi hal tersebut, yang terjadi di ruang publik lapau kopi di Nagari Talang Anau memiliki terminologi ruang publik yang sama dengan pemahaman Habermas bahwa ruang publik memiliki perbedaan tempat dan waktu, yang terdiri atas informasi dan debat politik, seperti berita surat kabar, majalah, dan insitusi- institusi politik seperti diparlemen, komunitas politik, salon-salon, pertemuan umum, rumah minum, kedai kopi, ruang pertemuan dan ruang publik lainnya yan terjadi diskusi sosial-politik.

\section{PENUTUP \\ Kesimpulan}

Berdasarkan hasil dari penelitian tersebut menggambarkan bahwa warung kopi atau istilah dalam Minangkabau khususnya Nagari Talang Anau merupakan salah satu bentuk ruang publik. Lapau kopi bersifat terbuka dan bisa diakses oleh siapa saja yang dapat membaur antara individu dengan individu lainnya. Aktivitas yang dilakukan di Lapau Kopi tidak hanya sebatas minum kopi atau teh saja pada umumnya, akan tetap di Nagari Talang Anau lapau kopi dijadikan sebagai tempat berdiskusi melepaskan beban pikiran dan melarutkan titik kejenuhan dari pekerjaan. Diskusi yang terjalin antara individu tersebut dimulai dari pembahasan yang ringan hingga permasalahan yang terjadi di Nagari Talang Anau dalam konteks social, ekonomi, politik dan budaya. Selain itu, perkembangan lapau kopi didorong karena adanya keinginan dari masyarakat dan kebutuhan akan keberadaan ruang publik. Perbincangan yang terjadi dilapau kopi ini menunjukkan suatu konsep musyawarah seperti dijelaskan dalam konsep demokrasi deliberatif memacu pada proses proses yang terjadi dalam penentuan suatu keputusan atau kebijakan. Proses yang dimaksud di sini adalah adanya musyawarah bersama di ruang publik yang menghasilkan opini publik yang mampu mempengaruhi kebijakan.

\section{Saran}

Berdasarkan hasil penelitian ini, peneliti mengajukan saran-saran sebagai berikut:

1. Peneliti berharap, keberadaan lapau kopi di Nagari Talang Anau tetap Copyright () 2020, Publik (Jurnal Ilmu Administrasi), ISSN: 2301-573X (Print), ISSN: 2581-2084 (Online) 
bertahan dengan kearifannya tanpa dicampuri oleh modernisasi, agar bermanfaat yang positif bagi masyarakat Talang Anau, sebagai sarana hiburan, diskusi, berkomunikasi yang memadai, sehingga menjadi sarana pembelajaran bagi demokratisasi publik.

2. Bagi masyarakat yang berkunjung ke lapau kopi, agar semakin dapat membuka diri selebar-lebarnya untuk dapat menyampaikan ide, gagasan bahkan keluhan terhadap pemerintah, melalui dialog/diskusi akan membuka sebuah informasi yang berujung pada pemecahan masalah dengan cara yang baik dan benar

3. Hasil penelitian ini juga diharapkan dapat menjadi masukan bagi peneliti lain serta dalam mempertahankan keberadaan lapau kopi sebagai identitas masyarakat yang telah ada sejak dulu.

4. Bagi penelitian lanjutan, demi perkembangan studi ilmu politik khususnya pada tataran mengenai ruang publik dan partisipasi politik, ada beberapa kekurangan dalam penelitian ini salah satu diantaranya yaitu penelitian ini hanya melihat peran lapau kopi sebagai bagian dari ruang publik yang mampu mempengaruhi partisipasi politik masyarakat di Nagari Talang Anau dengan menggunakan pendekatan penelitian kualitatif. peneliti menyarankan untuk diadakan penelitian lanjutan di lokasi penelitian sehingga menemukan penelitian yang benar-benar holistik (menyeluruh) untuk melihat seberapa besar pengaruh dari ruang publik terhadap partisipasi politik dengan tipe pendekatan penelitian kuantitaif., sehingga konsep ruang publik terhadap partisipasi politik ini dapat benar-benar berkembang untuk kemajuan ilmu politik kedepannya.

\section{Ucapan Terima Kasih}

Kegiatan penelitian ini dibiayai oleh Kemenristek BRIN melalui SKIM Penelitian Tesis Magister (PTM) dengan No Kontrak:T/56/UN.16.17/PT.01.03/PTM -Sosial Sumaniora/2020 Tanggal 10 Maret 2020. Untuk itu kami mengucapkan terima kasih kepada Kemristek BRIN dan LPPM Universitas Andalas yang telah mendanai penelitian ini serta semua pihak yang telah membantu kelancaran penulisan artikel ini.

\section{DAFTAR PUSTAKA}

Behrad B.\& Bahrani B. (2015). The impact of publik spaces physical quality in residential complexes on improving user's social interactions, case study; pavan residential complex of sanandaj. Iran J. Civil Eng. Urban. 5(2): 89-93.

Bhakti, S. E. (2020). Ruang publik dan media sosial: partisipasi politik mahasiswa indonesia. Jurnal Kajian Media 4 (1), 01-10.

Cassegard, C. (2014). Contestation and bracketing: the relation between publik space and the publik sphere. Environment and Planning D: Society and Space , 689-703.

Creswel, John W. (2016). Penelitian Kualitatif dan Desain Riset. Yogyakarta: Pustaka Belajar.

Gabbett, T., Jenkins, D., \& Abernethy, B. (2010). Physical collisions and injury during professional rugby league skills training. Journal of Science and Medicine in Sport, 13 (6), 578-583. 


\section{Available Online at http://journal.umgo.ac.id/index.php/Publik \\ Publik (Jurnal Ilmu Administrasi) Vol 9 (1), Juni 2020}

Jurnal IImu Administrasi

Geraldy, G. (2017). Sobo pendopo dialogue: manifestation of deliberative democracy in bojonegoro regency. Jurnal Sosiologi Reflektif. 12 (1)

Hardiman, Budi. (2010). Demokrasi Deliberatif; Menimbang Negara Hukum dan Ruang Publik dalam Teori Diskursus Jurgen Habermas. Sleman: Kanikus

Hardiman, Budi. (2010). Ruang Publik; Melacak Partisipasi Demokratis Dari Pollis Sampai Cyberspace. Yogyakarta. Kanikus

Iskandar, A. A. (2017). Pengaruh perilaku organisasi dan bauran pemasaran terhadap produktivitas warkop sebagai ruang publik di kecamatan rappocini kota makassar. Jurnal Economix. 5 (1) , 84-93.

Kadarsih, Ristiana. (2008). Demokrasi dalam ruang publik; sebuah pemikiran ulang untuk media massa di Indonesia. Jurnal Dakwah. 9 (1)

Kimbal, Marthen L. (2018). Partisipasi politik dalam proses pembangunan desa di kecamatan wori, kabupaten minahasa utara. Sosiohumaniora, Jurnal Ilmu Sosial dan Humaniora.

Kusno. Abidin. (2009). Ruang Publik, Identitas dan Memori Kolektif. Yogyakarta: Penerbit Ombak

Malik, A. (2018). Ruang publik sebagai representasi kebijakan dan medium komunikasi publik. Jurnal SAWALA (6) $2: 82-88$.

Nugroho, W. B., \& Kamajaya, G. (2019). Menakar idealitas lapangan puputan sebagai ruang publik masyarakat kota denpasar. Politika, Jurnal Ilmu Politik, 78-92.
Paskarina, Caroline. (2005). Dilema Ruang Publik Dalam Demokratisasi, Institute Of Governance Studies.

Prasetyo, A. G. (2012). Menuju demokrasi raional: melacak pemikiran jürgen habermas tentang ruang publik. Jurnal Ilmu Sosial dan Ilmu Politik, 169-185.

Valentina, Tengku Rika (2018). Dinamika Politik Lokal Di Minangkabau; Nagari dalam Negara dan Model Demokrasinya. Depok: Raja Grafindo Persada

Setiawan, N., Leksono, S., \& Sungkawati, E. (2020). Modal sosial pedagang kaki lima dalam memanfaatkan ruang publik untuk berjualan di pasar besar malang . Jurnal Penelitian Pengkajian Ilmiah Mahasiswa (JPPIM). 1 (1), 59-64.

Sugiyono. (2017). Metode Penelitian Kualitatif. Bandung: Alfabeta

Supriadi, Yadi. (2017). Relasi ruang publik dan pers menurut Habermas. Kajian Jurnalisme, 1(1)

Yin, Robert K. (2011). Studi Kasus; Desain dan Metode. Jakarta: Rajagrafindo Persada 